\title{
Gambling With Our Planet
}

\author{
Michael Barker ${ }^{1}$
}

Previous work has amply documented the cynical manner in which ruling class elites manipulate green concerns to legitimize class war. This study extends this literature by tracing the problematic influence of three members of the ruling class, who exemplify conservative advocacy of environmentalism: these being gambling legend cum zoo owner John Aspinall (1926-2000), billionaire financier Sir James Goldsmith (1933-1997) and his brother, the influential deep ecologist Edward "Teddy" Goldsmith (1928-2009). From John Aspinall's Zulu dreams and virulent anti-humanism, to the conspiratorially minded far-right pipe dreams of a corporate raider like Sir James Goldsmith, this article demonstrates that over the past several decades, advocates of green politics have had some distasteful and highly dangerous allies. And while Teddy Goldsmith is often held up as a grandfather of the modern environmental movement, his contributions to the ideological evolution of the green thinking turn out to be as reactionary as those of both Aspinall and Sir James. That the work of three such prime examples of the ruling class should have been able to encourage the institutionalization of quite so much inegalitarianism within an ostensibly liberal environmental movement clearly demonstrates the pressing need for a Marxist alternative to managing our world for the benefit of all. It is thus hoped that environmentalists can learn from the problematic legacy derived from such misanthropes, and continue to build movements capable of generating the type of popular momentum for social change that will eventually be capable of eradicating, and not just domesticating, capitalism. [Article copies available for a fee from The Transformative Studies Institute. E-mail address: journal@transformativestudies.org Website: http://www.transformativestudies.org (02014 by The Transformative Studies Institute. All rights reserved.]

KEYWORDS: Environmental, Ecology, Socialism, Traditionalism, Goldsmith, Aspinall.

\footnotetext{
${ }^{1}$ Michael Barker is a member of the Socialist Party (England and Wales). He has been writing for alternative media outlets since 2006, and at present is a regular contributor to Swans Commentary. His work has been published by the following media organizations: Ceasefire Magazine, Corporate Watch (UK), Countercurrents, CounterPunch, Dissident Voice, Fifth Estate Online, Green Left Weekly, Jacobin, Media-ocracy, Monthly Review Zine, New Community Quarterly, New Left Project, PULSE Media, Spinwatch, Socialist Project, State of Nature, Upside Down World, Variant, and in the past he was a regular contributor to Znet. Address correspondence to: Michael Barker, e-mail: mbarker@riseup.net.
} 